\title{
Educational innovation projects in Dutch higher education: bottom-up contextual coping to deal with organizational challenges
}

Martine Schophuizen ${ }^{1,2^{*}}$ and Marco Kalz ${ }^{3}$

* Correspondence: m.j.f. schophuizen@tudelft.nl

${ }^{1}$ Faculty of Educational Sciences, Open University of the Netherlands, Heerlen, The Netherlands ${ }^{2}$ LDE Centre for Education and Learning, TU Delft, Delft, The Netherlands

Full list of author information is available at the end of the article

\begin{abstract}
Understanding the process of initiation, design, implementation and embedding of educational innovations in higher education is necessary to develop better strategies for sustainable, large-scale educational innovation. Often early initiated educational innovation projects are not evaluated well enough, making it hard to identify lessons learned. The aim of this study is to investigate how project leaders of innovation projects in Dutch higher education institutions are coping with organizational challenges. To address this we analysed qualitative focus group data with innovators that run projects at Dutch higher education institutions through the lens of contextual coping theory. Results show that the innovators identified challenges (primary appraisal), proposed possible solutions (secondary appraisal) and also were able to take concrete steps (coping efforts) to overcome challenges to design and implement open online educational innovations. From these findings it can be concluded that bottom-up initiatives can create awareness and are capable of finding local resources to establish support for embedding innovations locally, yet, appropriate, synchronized and timely top-down action is needed in order to create a sustainable and institution wide support system for experimentation and embedding of educational innovations. These findings will contribute towards developing better strategies to develop innovative educational practices and quality education.
\end{abstract}

Keywords: Educational innovation, Organizational embedding, Coping theory

\section{Introduction}

With the rapid development of technology, higher education institutions (HEIs) are able to change their provision of education by developing new and innovative educational practices (Allen and Seaman 2014; Yuan and Powell 2013). Knowing how this process of initiation, design, implementation and embedding of educational innovations in HEIs works, helps to develop better strategies to do so.

Educational innovations do not generally start with big impact and scale. Often the initiation of innovation takes place in small-scale projects with limited resources driven by enthusiasm and commitment of individuals. Yet, there is a risk that these projects

(c) The Author(s). 2020 Open Access This article is licensed under a Creative Commons Attribution 4.0 International License, which permits use, sharing, adaptation, distribution and reproduction in any medium or format, as long as you give appropriate credit to the original author(s) and the source, provide a link to the Creative Commons licence, and indicate if changes were made. The images or other third party material in this article are included in the article's Creative Commons licence, unless indicated otherwise in a credit line to the material. If material is not included in the article's Creative Commons licence and your intended use is not permitted by statutory regulation or exceeds the permitted use, you will need to obtain permission directly from the copyright holder. To view a copy of this licence, visit http://creativecommons.org/licenses/by/4.0/. 
are not being continued beyond initial funding or piloting phase and therefore fail to have systematic impact on an organizational level (Collis and van der Wende 2002; Hannon 2009; Jenkins et al. 2010).

Reasons for the lack of impact on bigger scale may be found in innovation diffusion theory by Rogers (2002). According to him, adopters' perceptions of innovation characteristics are more important than the objective measures of them and the individual context contributes to the individual innovation adoption. Thus, projects that start small and driven by single individuals, might also remain on that level of impact. A related study by Zhu (2015) points to the fact that aspects of an organizational culture, such as goal orientation, innovation orientation of organizations, leadership, participatory decision making, shared vision and formal relationships among members are proven to be critical for perceived need and usefulness, responsiveness and adoption of technology-enhanced innovation. In addition, if appropriate and sufficient organizational support and incentives are not provided at the right moment, early adopters' efforts may attain only mediocre quality (Zellweger 2007). These findings indicate that effective and timely support from the top-down are key in addition to the role of pioneers in educational innovations as explained by Rogers (2002).

Although these, among other studies, give insights into the context of technology enhanced educational innovation, they only describe particular aspects of the innovation process and are often explored from a top-down perspective in which the actors from bottom-up are not taken into account as individual enablers for change. Additionally, since the process of innovation is not an autonomous, linear process, but part of a broader technology related transformation in higher education (Schneckenberg 2009), there is a need to rethink innovations and its accompanying process more broadly and placed in context to capture its' complexity and emergent nature (Nambisan et al. 2017). In summary, there is a need for empirical research on innovation in higher education that takes into account bottom-up agency of individuals and contextualizes the innovation process appropriately to account for its complex nature.

In this study we therefore aim to research experiences of innovators in HEIs with MOOCs as a form of open online education (OOE) by zooming in on the organizational challenges they encountered and assessing the way they dealt with these challenges. Because we would like to focus on the bottom-up perspective of these innovators, we adopt a contextual model of coping to find out how individuals think and act in relation to important changes that occur in their environment. We use a contextual model of coping instead of an ego-psychological or personality model, because the relationship and interdependence of individuals in a context is key to answer our research question.

We start with shortly describing the theoretical background of the research. We then introduce our methodology and report on the results. Lastly, we discuss implications of our findings for research and practice.

\section{Theoretical background}

Contextual coping can be defined as the cognitive and behavioural efforts utilized to manage specific external and/or internal demands that are considered as challenging or exceeding resources of a person (Beaudry 2009). Within this definition internal demands are individuals' requirements that the environment must meet. External 
demands originate from the environment and must be met by individuals. Both are connected to someone's role in a given context (e.g. HEI). In other words, the contextual perspective on coping is concerned with particular circumstances or incidents, taking place in the individual's environment. Because this model allows for different individual interpretations of situations, over time and within and between individuals, coping responses are not seen as a stable feature of a personality, but rather as a way to describe what a person does and thinks in a situation at a given point in time (Moos and Holahan 2003).

In coping theory, two processes that constantly influence each other are distinguished: appraisal, the cognitive assessment of a situation, and coping efforts, the behavioural efforts exerted to manage the given situation (Beaudry and Pinsonneault 2005). We will distinguish between these processes of coping because we do not only want to shed light on the occurred behaviours and actions, but we would also like to know how innovators reflected on and identified ways of potentially dealing with challenges, even though it might not always be possible to transform those thoughts into actions. Our main research question was: In what way did project leaders of educational innovation projects cope with organizational challenges that they encountered? We formulated three sub-questions to guide our research, These are described below.

The coping process starts with appraisal, and takes place in two steps. During primary appraisal the nature, importance and relevance of a situation is being assessed. An individual will try to determine what consequences a situation is likely to have and what the impact is on his resources (Folkman 1992). Our first sub question was: In what way did project leaders of educational innovation projects assess (i.e. primary appraisal) the organizational challenges they encountered?

Then, in secondary appraisal one will reflect on the available coping options in this situation given the resources they have available (Folkman et al. 1986; Lazarus and Folkman 1984). It is important to note that resources in this context can mean various things. For example material, physical and social resources as well as experience and skills. Secondary appraisal gives insight in the potential actions that can be taken, and may indicate also why, or why not this is seen as realistic in the given situation. Our second sub question was: How did project leaders of educational innovation projects reflect on (i.e. secondary appraisal) the coping processes available to them in relation to the organizational challenges they encountered?

The second subprocess, coping efforts, is behavioural, in which individuals take actions to deal with the situation at hand (Lazarus 1966). Because the coping process varies from one individual to the other, its related outcomes also vary. Problem-focused acts, may lead to solving the problem at hand, reducing the effective negative consequences, increasing one's related knowledge and skills, or decreasing uncertainty. The coping acts and their outcomes may also lead one to reappraise the situation and perform another wave of coping acts when problem solving is not an outcome of an initial coping effort. Consequentially, the third sub question was: What were the actions taken (i.e. coping efforts) by project leaders of educational innovation projects in relation to the organizational challenges they encountered?

The organizational challenges that we will focus on in this paper were identified in an earlier study by project leaders of educational innovation projects at various HEIs (Schophuizen et al. 2018). There were two core themes that were identified as the 
biggest challenges: online teaching and support mechanisms (see Table 1). For online teaching, challenges were related to the role of the teacher, attitudes and beliefs about online teaching and skills in designing and teaching in an online environment. Challenges in this theme imply a skills gap among teachers and ambiguity about what it entails to teach online. The second theme, support mechanisms, translates into a need for operational support and on the other hand a demand for a higher level of support in terms of organizational vision, strategy alignment, and policies supporting OOE. This study gave bottom-up insights into the aspects of organizational challenges. In the current study we will follow-up on these findings, investigate how these challenges were dealt with, and if these individuals were able to overcome them through the lens of coping theory.

\section{Methodology}

In this study we used directed qualitative content analysis to extend existing theory and contribute to the development of a theoretical base for institutional embedding of educational innovations (Hsieh and Shannon 2005), also referred to as deductive category application (Mayring 2000).

We arranged focus groups and applied purposeful (typical) sampling, where we intentionally selected individuals to find answers to our topic of interest to collect data (Creswell 2014). We organized two separate focus groups with 11 participants in total. Participants in the first focus group were 5 project leaders of educational innovation projects that received funding in 2015. In the second focus group there were 6 project leaders that received funding in 2016. The projects are located at 5 public universities, and 4 public universities of applied sciences (see Table 2). The funding for their projects was part of a national program initiated by the Dutch ministry of education, culture and science in 2015 that aims to stimulate educational OOE innovations in higher education (Surfnet 2017). Before data collection, these project leaders, from now on referred to as innovators, were informed about the goal, procedure and handling of their data and were asked to confirm that they understood the instructions in an informed consent.

Table 1 Organizational challenges that are experienced as important for success of educational innovation projects (Schophuizen et al. 2018)

\begin{tabular}{ll}
\hline Cluster & Challenges \\
\hline Online teaching & - The objective why to use OOE is unclear among teachers \\
& - Merits of OOE are unclear to teachers \\
& - Time available to teachers to develop OOE is scarce \\
& - Preparing and teaching in traditional education requires a different skill set than for OOE, \\
& difference in workflow is often not recognized \\
& - Teacher skills in online teaching are often absent/limited \\
& - OOE teacher skill development not part of teacher professionalisation \\
& - Consequences of open publication and re-use unclear among teachers \\
& - Reluctance of teachers to share educational resources \\
& - Changing role of the teacher \\
& - Online interactions with students require different skills from teachers compared to \\
& traditional education \\
& - Suitable technical facilities for recording and editing \\
& - Lack of clear OOE policy on an institutional level \\
& - Lack of organised ICT support \\
Support & Lack of a support department with OOE experience \\
mechanisms & - Lack of support of the university board for OOE initiatives \\
& - Lack of infrastructures and support on these infrastructures for OOE
\end{tabular}


Table 2 Sample description (UoAS: university of applied sciences)

\begin{tabular}{lll}
\hline Year funded & Institution & Project kind \\
\hline $\mathbf{2 0 1 5}$ & Utrecht University & OER \\
& Leiden University medical center & OER \\
& Leiden University & MOOC \\
& University of Amsterdam & MOOC \\
& UOAS NHL/Haagse & MOOC \\
& Utrecht University & OER \\
& Twente University & Tool/Platform \\
& Twente University & OER \\
& Maastricht University & Platform/MOOC \\
& UOAS Utrecht & OER \\
& UOAS Amsterdam & MOOC \\
\hline
\end{tabular}

The focus groups were audio recorded and transcribed into smooth verbatim transcripts for further analysis. For deductive category application, we formulated a thematic coding scheme based on the identified organizational challenges as found by the previous study by Schophuizen et al. (2018) (see Table 3).

After our first round of thematic coding we applied a second round of coding to gain insight on the coping of the innovators by using a coding scheme based on contextual coping theory (Beaudry and Pinsonneault 2005; Lazarus and Folkman 1984). In the development of the coping coding scheme, we distinguished between three coping subprocesses primary appraisal and secondary appraisal as cognitive subprocess and the behavioural subprocess: coping efforts (see Table 4). By coding primary appraisal we looked for concluding remarks about the identified challenge, assessing the nature, importance and relevance of a situation. By coding secondary appraisal we looked for reflection of the innovators on the coping processes available to them in this situation, and if they expressed any ideas in terms of solutions to apply next time. With coping efforts we aimed to look at actual behaviour that was shown during their project time, in other words where innovators took actions to deal with the situation at hand when running their projects. By coding on both themes (i.e. organizational challenges) and contextual coping categories (i.e. cognitive and behavioural) we gain an insight specifically focused on challenges and how these can be dealt with. After the coding procedure

Table 3 Thematic coding scheme

\begin{tabular}{ll}
\hline Categories & Codes \\
\hline Online teaching & C1 Skills gap for developing OOE \\
& C2 Skills gap for teaching in OOE \\
& C3 Lack of awareness of goal and merits of OOE \\
& C4 Reluctance to use/participate in OOE \\
& C5 Time constraints of teachers \\
Support mechanisms & C6 Changing role of the teacher \\
& C7 Lack of operational support \\
& C8 Lack of strategic support \\
& C9 Lack of policy in the organization \\
\hline
\end{tabular}


Table 4 Coping coding scheme

\begin{tabular}{ll}
\hline Categories & Codes \\
\hline Cognitive coping processes & C10 Primary appraisal \\
Behavioral coping process & C11 Secondary appraisal \\
\hline
\end{tabular}

we charted the data, which is to the process of synthesizing data and locating it within the thematic framework that we developed.

\section{Results}

Table 5 presents a frequency overview as a result of our coding application. In Table 6 we summarize the main findings by charting the focus group data. The aim of this paper was to investigate how innovators projects in HEIs are dealing with encountered organizational challenges. We will first discuss a general overview of our results and consequently we will focus on our sub questions, which will altogether contribute to the answer of our main research question.

\section{General results}

In the frequency overview we see that some aspects were more apparent in the data than others (see Table 5). Themes that were present in the data were: C1 Skills gap for developing OOE, C3 Lack of awareness of goal and merits of OOE, C6 Changing role of the teacher, C7 Lack of operational support, C8 Lack of strategic support and C9 Lack of policy in the organization.

The themes that were not discussed were: $\mathrm{C} 2$ Skills gap for teaching in OOE, C4 Reluctance to use/participate in $O O E$ and C5 Time constraints of teachers. An explanation for this could be that all the projects leaders were at the stage where they finished the development of their projects, due to delay or initial planning, and did not have the chance to implement and run it in an educational setting yet. For this reason, we excluded these challenges from further analysis.

Additionally, we observe some differences in the frequency of coping categories. There are more cognitive coping observations (i.e. primary and secondary appraisal) than actual behavioural actions (i.e. coping efforts). This reflects that at the project

Table 5 Initial codes and secondary codes and their frequencies

\begin{tabular}{lllll}
\hline Codes & C10 & C11 & C12 & Total \\
\hline C1 & Primary appraisal & Secondary appraisal & Coping efforts & \\
C2 & 11 & 16 & 13 & 40 \\
C3 & 1 & 0 & 0 & 1 \\
C4 & 18 & 12 & 4 & 34 \\
C5 & 1 & 3 & 1 & 5 \\
C6 & 2 & 2 & 2 & 6 \\
C7 & 10 & 11 & 2 & 23 \\
C8 & 9 & 10 & 7 & 26 \\
C9 & 7 & 10 & 3 & 20 \\
\hline
\end{tabular}


Table 6 Charting of focus group data

\begin{tabular}{|c|c|c|c|}
\hline & \multicolumn{3}{|l|}{ Coping codes } \\
\hline & C10 Primary appraisal & C11 Secondary appraisal & C12 Coping efforts \\
\hline \multicolumn{4}{|c|}{ Thematic Codes (online teaching) } \\
\hline $\begin{array}{l}\text { C1 Skills gap } \\
\text { for } \\
\text { developing } \\
\text { OOE }\end{array}$ & $\begin{array}{l}\text { Form and status of } \\
\text { materials regarded } \\
\text { differently: } \\
\text { - Knowledge about } \\
\text { possibilities and } \\
\text { appropriate forms missing } \\
\text { - Development of materials } \\
\text { seems more definitive and } \\
\text { less easy to adjust } \\
\text { - Use and reuse of materials } \\
\text { ambiguous and complex } \\
\text { Teacher practices more } \\
\text { distributed: } \\
\text { - Involvement of external } \\
\text { and multiple stakeholders } \\
\text { - Communication with all } \\
\text { stakeholders }\end{array}$ & $\begin{array}{l}\text { Consideration of form, media } \\
\text { and learning objectives } \\
\text { - Consider use and reuse } \\
\text { possibilities } \\
\text { - Adjust the form of the } \\
\text { materials specifically to } \\
\text { learning objectives and } \\
\text { requirements } \\
\text { Involvement of more } \\
\text { stakeholders in the } \\
\text { development process: } \\
\text { - Incoporate teachers and their } \\
\text { preferences } \\
\text { - Make use of expertise of } \\
\text { external bureaus and media } \\
\text { parties } \\
\text { - Involvement of library in data } \\
\text { management } \\
\text { Sharing of knowledge: } \\
\text { - Platform/central portal or } \\
\text { meeting opportunities to gain } \\
\text { ideas and knowledge }\end{array}$ & $\begin{array}{l}\text { Planning } \\
\text { - Consider major time } \\
\text { investment beforehand } \\
\text { - Consider multiple } \\
\text { stakeholders } \\
\text { - Don't underestimate } \\
\text { coordination of tasks and } \\
\text { responsibilities } \\
\text { Seeking support: } \\
\text { - Coaching by external } \\
\text { expertise } \\
\text { - Supporting tools (e.g. } \\
\text { autocue) } \\
\text { - Make use of informal } \\
\text { networks to find expertise } \\
\text { Create possibilities to } \\
\text { experiment: } \\
\text { - Make use of local/bottum } \\
\text { up resources (e.g. budget } \\
\text { form local bodies for for } \\
\text { example equipment) } \\
\text { - Set up local workshops }\end{array}$ \\
\hline $\begin{array}{l}\text { C2 Skills gap } \\
\text { for teaching } \\
\text { in OOE }\end{array}$ & $\mathrm{n} / \mathrm{a}$ & $\mathrm{n} / \mathrm{a}$ & $n / a$ \\
\hline $\begin{array}{l}\text { C3 Lack of } \\
\text { awareness of } \\
\text { goal and } \\
\text { merits of } \\
\text { OOE }\end{array}$ & $\begin{array}{l}\text { The commons idea } \\
\text { behind OOE is missing: } \\
\text { - Individualistic attitude } \\
\text { - Forced extrinsic motivation } \\
\rightarrow \text { no intrinsic value } \\
\text { creation } \rightarrow \text { ambiguous } \\
\text { knowledge of OOE } \\
\text { Not being able to see } \\
\text { multiple applications of } \\
\text { OOE materials } \\
\text { Management does not } \\
\text { pick up on bottom up } \\
\text { initiatives }\end{array}$ & $\begin{array}{l}\text { Sharing of knowledge: } \\
\text { - Platform/central portal with a } \\
\text { collection of ideas and good } \\
\text { practices to get inspired } \\
\text { Incentivise OOE development } \\
\text { and teaching innovations } \\
\text { Adapted and personalised } \\
\text { training possibilities }\end{array}$ & $\begin{array}{l}\text { Sharing knowledge: } \\
\text { - Share examples with direct } \\
\text { colleagues } \\
\text { - Emphazise the gains for } \\
\text { others in their contexts } \\
\text { - Project as organizational } \\
\text { signal }\end{array}$ \\
\hline $\begin{array}{l}\text { C4 } \\
\text { Reluctance } \\
\text { to use/ } \\
\text { participate in } \\
\text { OOE }\end{array}$ & $\mathrm{n} / \mathrm{a}$ & $\mathrm{n} / \mathrm{a}$ & $n / a$ \\
\hline $\begin{array}{l}\text { C5 Time } \\
\text { constraints } \\
\text { of teachers }\end{array}$ & $\mathrm{n} / \mathrm{a}$ & n/a & $\mathrm{n} / \mathrm{a}$ \\
\hline $\begin{array}{l}\text { C6 Changing } \\
\text { role of the } \\
\text { teacher }\end{array}$ & $\begin{array}{l}\text { Ownership: } \\
\text { - Of educational material } \\
\text { distributed } \\
\text { - Process of producing } \\
\text { material distributed } \\
\text { - New requirements for } \\
\text { teaching } \\
\text { - Reluctance of teachers } \\
\text { accepting a tasks/roles } \\
\text { - Control over choices in the } \\
\text { design process distributed } \\
\text { Emphasis on educational } \\
\text { design over teaching }\end{array}$ & $\begin{array}{l}\text { Role distribution: } \\
\text { - Make it a collective effort } \\
\text { - Find fitting roles } \\
\text { - Make solid agreements on } \\
\text { roles and responsibilities } \\
\text { - Invest time and effort in } \\
\text { continuously checking role } \\
\text { distribution and expectations } \\
\text { - Involve stakeholders internally } \\
\text { to fulfill new roles (e.g. library) }\end{array}$ & $\mathrm{n} / \mathrm{a}$ \\
\hline
\end{tabular}

Thematic Codes (support mechanisms) 
Table 6 Charting of focus group data (Continued)

\begin{tabular}{|c|c|c|c|}
\hline & \multicolumn{3}{|l|}{ Coping codes } \\
\hline & C10 Primary appraisal & C11 Secondary appraisal & C12 Coping efforts \\
\hline $\begin{array}{l}\text { operational } \\
\text { support }\end{array}$ & $\begin{array}{l}\text { - Decisions on IT on higher } \\
\text { level sometimes hinder } \\
\text { OOE design } \\
\text { - Not sufficiently adjusted to } \\
\text { requirements for OOE (i.e. } \\
\text { is one size fits all) } \\
\text { - Hard to find the } \\
\text { appropriate support }\end{array}$ & $\begin{array}{l}\text { - Strategic choice of institution } \\
\text { - Centrally located } \\
\text { - Adjusted and personal advice } \\
\text { Roles: } \\
\text { - Content and format experts } \\
\text { equally important } \\
\text { - Clear distribution of tasks and } \\
\text { responsibilities } \\
\text { Professionalization on OOE } \\
\text { skills: } \\
\text { - Formal requirement (e.g. part } \\
\text { of incentive structure) } \\
\text { - Training (e.g. as part of a BKO) }\end{array}$ & $\begin{array}{l}\text { - Involve decsion makers } \\
\text { from higher levels early on } \\
\text { - Find where crucial decisions } \\
\text { are being taken } \\
\text { The power of bottom up: } \\
\text { - Find capacity in own circle } \\
\text { of influence } \\
\text { - Access to resources at local } \\
\text { budgets } \\
\text { - Creation of awareness }\end{array}$ \\
\hline $\begin{array}{l}\text { C8 Lack of } \\
\text { strategic } \\
\text { support }\end{array}$ & $\begin{array}{l}\text { Involvement management } \\
\text { - Long term choices taken } \\
\text { at higher levels (e.g. } \\
\text { infrastructure) } \rightarrow \text { hard to } \\
\text { influence } \\
\text { - Management not involved } \\
\text { throughout the whole } \\
\text { process } \\
\text { - Funding during project } \\
\text { period, ends after }\end{array}$ & $\begin{array}{l}\text { Role models: } \\
\text { - Chairs in Open Education } \\
\text { (professorships) } \\
\text { - Put good work and examples } \\
\text { in the spotlight (e.g. rewards) } \\
\text { Incentive structures: } \\
\text { - Rewarding more than just } \\
\text { teaching and research } \\
\text { Structural funding: } \\
\text { - Included in institutional } \\
\text { budgets of HEls for } \\
\text { experimentation } \\
\text { oOE for non-formal } \\
\text { educational purposes to } \\
\text { build capacity: } \\
\text { - Pre-master } \\
\text { - Pre-university } \\
\text { - Extra curricular } \\
\text { - Additional materials } \\
\text { (complementary to existing } \\
\text { curricula) }\end{array}$ & $\begin{array}{l}\text { Informal information } \\
\text { sharing } \\
\text { - Source of information for } \\
\text { colleagues } \\
\text { - Source of inspiration for } \\
\text { colleagues } \\
\text { - Sharing project outcomes }\end{array}$ \\
\hline $\begin{array}{l}\text { C9 Lack of } \\
\text { policy in the } \\
\text { organization }\end{array}$ & $\begin{array}{l}\text { Top-down facilitation: } \\
\text { - Overarching commons } \\
\text { vision needs overarching } \\
\text { stimulation } \\
\text { Strategic choices not } \\
\text { fitting operational needs: } \\
\text { - IT choices }\end{array}$ & $\begin{array}{l}\text { Connecting levels within HEl: } \\
\text { - Bottom up enthusiasm goes } \\
\text { hand in hand with top-down } \\
\text { facilitation (e.g. time given, } \\
\text { resources available, } \\
\text { experimentation room) }\end{array}$ & $\begin{array}{l}\text { Bottom-up persistence: } \\
\text { - Arrange equipment, studio } \\
\text { and funding locally } \\
\text { - Better uptake throughout } \\
\text { the organization } \\
\text { Appealing to external } \\
\text { professional communities: } \\
\text { - Funding } \\
\text { - Long term sustainability } \\
\text { - Broad uptake outside HEl } \\
\text { (legitimization) }\end{array}$ \\
\hline
\end{tabular}

runtime, the project leaders encountered challenges that they could not act on immediately, or were not able to act on from their bottom-up position. However, often they were able to assess the situation and find explanations for not being able to act (i.e. primary appraisal), or they expressed ideas how to approach things differently in a new situation, or how top-down actions could help in order to overcome challenges (i.e. secondary appraisal).

\section{Primary appraisal (sub RQ 1)}

In our first sub research question we aimed to give more insight in this cognitive aspect of coping by the project leaders. The perceptions that they expressed reflect a cognitive situational assessment and the influence on the process of implementation. 


\section{A different form and status of materials in $O O E$}

The form and status of the materials that need to be developed in an OOE context are regarded different compared to traditional education according to the innovators. Developing material in an open and online context is experienced as more "final" and less "easy to adjust" compared to some traditional face to face forms of education. This notion also creates more complexity and ambiguity for the use and reuse of open educational resources (OERs), especially when they are developed by others and taken out of context. Ownership becomes then also an issue for lifecycle of OERs. Additionally, it was also mentioned that the economic gain (i.e. saving teacher time during preparation), by using and reusing OERs, sometimes doesn't automatically also lead to didactical gains, and sometimes was even seen as resulting in didactical loss (e.g. not being able to adjust content easily). Additionally, it was also experienced that it is sometimes difficult to envision alternative applications of the available OERs, which means that economically these materials are not reused to their fullest potential.

\section{Unbundling: distributed teacher practices}

Innovators indicate that teacher practices, when developing OOE, are regarded as more distributed. This is attributed to the involvement of external and multiple stakeholders during the development phase. Communication and coordination is therefore experienced as more complex compared to traditional education. A quote to illustrate this is the following: “... in a traditional situation, you as a teacher, are in control of a course where you get a classroom and a certain group of students. This is something I don't need think about or organize. And now all of a sudden I needed a studio on a certain point in time, and others needed to clear their agenda. And on top of that, you also work with external media companies, that are used to working on very short notice. Well, if you work in education we are used to planning appointments two months ahead. This created very 'interesting' dynamics.".

Increased distributed practices is also discussed in the literature as "unbundling" as an outcome of the massification of national systems, the use of technology in education and increased specialisation of academic roles (Macfarlane 2011). A recent study by Kebritchi et al. (2017) stresses the impact of digital technologies on the unbundling process.

\section{Ownership of teaching practices}

Next to the notion that distributed practices makes the process of educational innovation more complex for teachers, it also changes their ownership over their teaching practices. Participants indicate that some teachers might feel reluctant to accept new roles and tasks, and giving up others when developing open online education, compared to the roles and tasks that are required for traditional education. The following quote illustrates this notion: "...an important difference between open online education and traditional education is that the educational design is becoming a more central aspect in the case of open online education. In traditional education, as a teacher, you just teach and perform tasks. Sometimes you think of new things to teach, 
but often it is the case that you take over a course from a colleague, and just ask what he or she has been doing the past year...".

This changing role of the teacher has also been recognized in previous research in which the role of the teacher is redefined in the context of networked learning environments (Ozturk 2015). In short, instead of being the central individual that delivers content and instruction, they become critical friends, mediators, and facilitators in designing and delivering education.

\section{The missing idea of OOE as a common good}

Innovators indicate that the broader societal idea behind OOE, where it is seen as a common good, is absent among staff of HEIs. A quote by one of the participants describing what his experience is in his institution with regard to developing OOE: "..people think like, what is in it for me? What will it bring me? What will it cost me? Focused on their own institution, and not considering what value it could have for others...". Consequently, there seems to be an individualistic attitude among the people working at HEIs, in which own individual return on investment and gains are prioritized over the overarching potential benefits of OOE.

Additionally, because mainly extrinsic incentives (e.g. funding) are in place to motivate people to start working with $\mathrm{OOE}$, intrinsic motivation to contribute to this overarching purpose, will remain ambiguous according to the participants. In their viewpoint this results in the lack of a wider awareness across the organization towards this purpose of OOE. Additionally, participants notice that this lack of awareness also is related to a use of educational technology terms and concepts related to openness in education that are not backed up with a deep level of understanding of what these actually mean and imply. The following quote illustrates this: "Open online education has the same issue as blended learning, it is one of these things that everybody is talking about. And then, when you ask a teacher: 'what he or she actually means by this?' You get an answer like: 'Every now and then I refer to a video'... Nobody actually has any idea of what blended learning is, or what you could do with it or want with it. But they all understood that 'blended learning' is now a buzz word, and you also see this issue with open online education. There is no deeper supported content driven vision. We should be careful with this.".

This level of unclarity could result in dysfunctional educational crosstalk where these individuals are going in different directions, framing teaching practices based on different ideas (McGrath and Bolander Laksov 2014; McGrath et al. 2017). These findings relate to work done by Nascimbeni and Burgos (2016), in which they explain that it is vital to work on the transition that educators go through towards using open online education, especially for awareness and capacity building. They propose that a reason for lack of focus on these transition phases is absence of a definition that encompasses openness within teachers' activities as a whole and that the transition of teachers towards openness must be seen in a broader change process, connected both with the higher education system as also the technical affordances that are becoming available for teaching. This emphasis on seeing this transition as a broader process indicates that to increase deeper awareness on OOE among educators an institutional effort would be appropriate (Evans and Myrick 2015). 


\section{Management involvement, strategic choices and top-down facilitation}

It is experienced by the innovators that the managerial layers of the organizations do not always notice and suitably facilitate bottom-up initiatives. For example, the management will make a choice for a certain tender for a learning management system, which makes it difficult to convince the management to additionally spend budget on another platform that fits other needs. In other words, strategic choices sometimes don't fit operational needs, and could be better connected. This also holds for basic technical support. Innovators mention that it is hard to find appropriate support that fits their needs for developing OOE in the organization.

\section{Secondary appraisal (sub RQ 2)}

As we explained earlier, during the process of secondary appraisal there is more insight in the potential actions that can be taken in a given situation. Although secondary appraisal is still cognitive, and does not reflect actual behaviour, it indicates why, or why not certain potential actions are realistic in a given situation. Although it remains cognitive, it could be important for the development of future implementation strategies to define requirements related to resources beforehand, instead of ad-hoc.

\section{Explicit consideration of form, media and learning objectives}

It is mentioned by the participants that it is important to explicitly consider the form and its in relation to the learning objectives that are aimed at. This requires a better understanding of the possibilities of new media, and a careful consideration early on in the process of educational design.

\section{Sharing of knowledge}

Following from the first argument to better consider form, it is seen as important to work on a structural way to share knowledge and good practices in order to gain and/ or share more insight into possibilities of form and media. Innovators mention for example a centrally available platform or portal with a collection of these good practices, or periodical seminars or other meeting possibilities in the institution. Additionally, structurally sharing ideas and knowledge may also serve as a way to inspire others and create awareness. On a higher level in the organization, awareness can be created through showing how OOE could fulfil non-formal educational purposes, such as teaching pre-master students or use in short educational programs to recruit new student groups. Showing managerial levels in the institution how OOE could serve multiple purposes increases also the willingness to consider future funding or support.

\section{Roles and role distribution}

The innovators indicate that it would be wise to involve more stakeholders early on in the development process, to overcome the difficulties that are encountered with distributed practices and lack of awareness of OOE. They put special emphasis the following stakeholders: (fellow) teachers and their preferences, the experts from external agencies and companies (e.G. media parties) that they work with in order to design the initiative, and the university library and their expertise on data management. The following quote illustrates the latter: "If teachers don't have the skills to use and implement metadata to 
organize the open educational resources, you involve the library to do this. Although this might be a new role for them, they actually like to do this."

This notion goes together with more emphasis on role distribution and making the educational design a shared effort opposed to an individual task. Stepping away from seeing educational design as an individual task also means that content and format experts need to be regarded as equally important. It is therefore essential to find fitting roles and tasks with specific individuals, and to make solid agreements in order to make this transparent and to manage expectations. Also, this role distribution and the agreements surrounding it, should be continuously checked. This goes in accordance with the notion of unbundling role of the teacher and distributed teaching practices.

\section{Role models, reward and incentive structures}

The innovators put forward that there is an important function for role models in the institution to gain more awareness about OOE and its possibilities. This could be done in a formal way, by appointing a chair or professor on Open Education, or in a more informal manner by putting exemplar initiatives in the spotlight to attracting attention to them and to award the innovators in the organization that are responsible for creating these initiatives. The following quote describes this: "I prefer the reward of individual enthusiasm, I think that is a good strategy. So if I would like more people to get involved in creating open online education, I think people that are already doing this should be stimulated. Those people should receive some backing up, they should see some nice examples. Or some kind of board member should install a chair on open education, to also formally show that this is something desirable".

Putting forward an incentive structure could then also serve as a formal way to award individuals for efforts towards working with open online education as mentioned by the innovators. The innovators suggest that this could be stimulated by not only rewarding teaching and research generally, but put more specific emphasis on what should be rewarded.

\section{Central and structural funding, training possibilities and teacher professionalisation}

Innovators put forward that it would be good if institutions would stimulate experimentation possibilities by means of extending funding for innovation projects by structurally including this in the internal budgets. Making experimentation not only dependent on external funds, will help to increase adoption, implementation and longterm sustainability of these initiatives. The following quote illustrates this: "What we now have tried out with these government funded projects, should now also be incorporated in the institutional budgets to continue our efforts".

They state that bottom-up enthusiasm goes hand in hand with top-down facilitation. By facilitation they refer to time given, resources available and room for experimentation. Emphasis is placed on having access to resources structurally so there will be room for continuous development. Some institutions have initiatives already geared towards this goal. Yet there is still room for improvement. The following quote underlines this: "University wide we now have a center that provides funding to stimulate projects related to open online education or blended learning... The advantage of this is 
that this creates room to experiment, and try out new things. However, I don't really see that any continuity is developing from this yet.".

In relation to this, there is a need for teacher professionalization on OOE skills. Innovators talk about how this could be stimulated in terms of training and consultancy that is centrally organized in the institution, so everybody who seeks coaching or training has easy access to it. Also, it should be noted that this training then should adapted and tailored to specific local needs of innovators and teachers.

\section{Coping efforts (sub RQ 3)}

As we explained above, coping efforts are behavioural. At this stage of coping individuals take actions and exert certain behaviours to deal with the situation they encounter. This may lead to solving encountered challenges, or finding ways to work around them by reappraising the situation and performing alternative waves of coping efforts. We looked into these behavioural aspects by means of our third sub question.

\section{Planning and involvement of decision makers}

As was already discussed, the distributed teacher practices and unbundling role of teachers is causing some complexity during the design phase of open online education. Preparation time increases, due to the involvement of various stakeholders, with multiple interdependent tasks. The innovators therefore put forward that careful planning is key in managing these complexities. It is suggested that teachers that want to develop open online education should take into account a major time investment for coordination of tasks and responsibilities, and also continuously follow up on this planning in order to check if it goes accordingly.

Additionally, to also ensure that other levels and departments of the organization are aware of the development of open online education initiatives, it is wise to involve decision makers early on in the process of projects. Especially when these levels and departments don't have any role during the development phase, but could play an important part with regard to long term sustainability or eventual communication of the project (e.g. quality assurance boards, marketing/communication departments). Innovators talk about that it is important to look where potential important future decisions are taken, and then invite and involve these individuals already in early stages of the process.

\section{Seeking support: coaching and informal networks}

By seeking support most innovators were able to overcome the skills gap they encountered. First of all, they talk about how they were able to find coaching by external experts on areas they were not familiar with. An example is given in the by an innovator who was developing a video report based on various cases, she says: "A video production company was helping us with the production, and they carefully look at which words to use and signalling to keep the listener engaged. This was simply fantastic, I was never coached in this manner, and I never prepared a lecture in this way". From this quote and other examples in our data we can say that coaching by external experts brings in new ways of thinking about form, and new knowledge on how to effectively bring across a message in an educational context. Not only coaching by people often helped, but also often tools served as a 'coach' for the innovators. The following quote 
provides an example: "We noticed there was a big difference between teachers. I myself recorded one of the first video's. I think mine turned out kind of clumsy, if I compare it to other ones, and now I know what is possible. Other teachers had some difficulties in doing things 'on the fly' and they were supported by using an autocue. Those video's turned out fantastic, and it looks really natural!".

Second, innovators were seeking support by looking into informal networks available to them. Although in many institutions a central support mechanism or body is not yet available, there are often individuals that have experiences in some form that could be valuable to learn from. Although it takes time and effort to find these individuals, once they are found they served as a valuable source of information for knowledge on design of open online education.

\section{Creation of experimentation possibilities: central action and bottom-up persistence}

The innovators talked about the importance of having experimentation room to learn how to develop open online education, and improve on skills that are required for this. In many cases the support seeking activities of the innovators, when taking place on larger scale and for a longer period of time, already lead to centrally organized initiatives. Some innovators mention how there are now studio's made available to experiment, or that workshops are now being centrally organized. The following quote illustrates this: "We now have a lab, with a studio and a place where we can experiment with blended forms of education. Because blended does not only mean that you are online, but also how you can integrate offline and online education well. These is going well, and you see more and more people booking a room there to go and experiment. It can be spread out much wider and broader in the organization, but we clearly made a start".

Nevertheless, if central initiatives are not being established, some innovators were also able to create some of these experimentation facilities themselves from the bottom-up by addressing local budgets of for example ICT and media departments. By not having to go through several layers of the organization, and investing time in convincing managers and leaders in order to get funding to create a room for experimentation (e.g. equipment and related materials), local 'do it yourself' experimentation rooms were developed. A quote to illustrate this is the following: "We noticed that when we asked for things it was difficult to get money from central budgets. When we asked from bottom-up, for some technical things for example, we succeeded by just asking our local video department that understood our needs.".

Although bottom-up creation of experimentation room may be a solution to a problem locally and serving a purpose for creating awareness, it might be a challenge to provide this kind of support institution wide if this is the starting point. If this kind of room for experimentation and support is not available to all, educators will be left with the immense task of designing and developing open online education on top of their other responsibilities. This will put a burden on how they perceive the use of open online education in their teaching practices, and indirectly this may also mean that students will be less satisfied. As found in work by Bolliger and Wasilik (2009), faculty satisfaction and student success are closely related. Consequently, without some level of institutional support institution wide adoption and embedding of OOE seems not 
realistic. Also other research suggests that educational innovations need to be a part of a broader organizational context and centrally coordinated in order to be successful (Russell 2009). Support from management and leadership become critical factors for long term sustainability of these facilities that support embeddedness of educational innovation (Birch and Burnett 2009). In sum, bottom-up initiatives can create awareness and are sometimes even capable of finding local resources to establish support, but top-down action is needed in order to create a sustainable and institution wide support system for experimentation and embedding of educational innovations.

\section{Sharing knowledge: internal and external}

As sharing knowledge was already mentioned as one of the possible solutions for a lack of awareness of OOE in the organization under our previous section, innovators also talked about some concrete examples in what ways they actually did this internally in their organizations. For instance, they acted as a source of information and inspiration for other colleagues by simply running their projects and talking to people about this. Additionally, also they regarded sharing project outcomes as one of the key activities to increase knowledge and awareness of OOE, as the following quote also illustrates: "Our project has been a sort of example and incentive for others to get enthusiastic to treat form and content of education differently. I think just running these projects works like this" and: "Within our university I notice more and more people are now starting to work with open online education. And because I have this project, they know how to find me, they call me, and then I tell them what we all did wrong, in the hope they can do a better job".

Another point that was mentioned was a way to externally communicate and share knowledge to increase awareness for a broad uptake outside the own HEI towards longer term sustainability and potentially external funding. An example of which groups to target were professional communities in the knowledge domain for which the initiative was developed.

\section{Discussion}

In this article we analysed how innovators of educational OOE innovation projects coped with organizational challenges during their implementation of educational innovation projects and contributed to the development of a theoretical base for institutional embedding of educational innovations. Contextual coping theory was adopted to account for individuals' adaptation behaviours conducted in response to changes that occur in their environment. Coping theory offered a lens through which to study how and why individuals adapt to technology in organizations. It also gives a richer understanding of a complex phenomenon, moving beyond describing what is lacking, towards giving insights into the agency of individuals within the structure of their organization.

Results show that the innovators identified challenges (primary appraisal), proposed possible solutions (secondary appraisal) and also were able to take concrete steps (coping efforts) to overcome challenges. For primary appraisal, we found that innovators identified that different form and status of materials, the distributed nature of teacher practices and ownership over these practices and the missing idea of OOE as a common good were the biggest challenges that obstructed the success of their initiatives. 
For secondary appraisal, they put forward that explicit consideration of form, media and learning objectives, sharing of knowledge, a clear definition of roles and role distribution, the function of serving as role models, appropriate reward and incentive structures, central and structural funding, training possibilities and teacher professionalisation were solutions to overcome organizational challenges they encountered, yet they were not able to transforms these into actions. For coping efforts, the actions they were able to perform as solution to encountered challenges, they put emphasis on planning, involving decision makers, sought support by means of coaching and informal networks, created experimentation possibilities through central actions and bottom-up persistence and shared knowledge internally and externally.

\section{Conclusion}

The results of this study are an empirical identification of bottom-up perspectives on implementation of educational innovation projects, and shed light on individual actors as enablers for change. This was shown through coping theory and specifically the results on the level of coping efforts show that educational innovation projects that start on a small scale and individual bottom-up level, could initiate changes that potentially could grow into impact on bigger scale. For example by involving decision makers in their organizations in an early stage of the process, by seeking support and coaching from external stakeholders and informal networks, by creating their own time and space for experimentation and sharing this with direct colleagues and lastly also sharing knowledge internal and externally in their organizations. Yet, top-down action is needed in order to create a sustainable and institution wide support system for experimentation and embedding of educational innovations. This can be seen in the light of previous research and literature but with the key difference that initiation of organizational change for embedding educational innovation does not need to be started from the top-down by default. In the case of our study it shows that both top-down and bottom-up efforts within HEIs both need to be taken in consideration, constantly need to be adapted to each other and synchronized in order to establish organizational embedding that meets the non-linear nature of innovation. These findings contribute towards developing better strategies for HEIs to developing new and innovative educational practices.

\section{Acknowledgements}

Not applicable.

Authors' contributions

Conceptualization: MS \& MK; Methodology: MS; Analysis: MS \& MK; Writing—original draft preparation: MS \& MK; Writing-review and editing: MS \& MK. The author(s) read and approved the final manuscript.

Funding

This work is financed via a grant by (NRO/NWO) and the Dutch Ministry of Education, Culture \& Science (grant: 40515-705).

Availability of data and materials

The datasets generated and/or analysed during the current study are not publicly available due to privacy reasons and compliance with GDPR rules and ethical standards but are available from the corresponding author on reasonable request.

Competing interests

The authors declare that they have no competing interests.

${ }^{1}$ Faculty of Educational Sciences, Open University of the Netherlands, Heerlen, The Netherlands. ${ }^{2}$ LDE Centre for Education and Learning, TU Delft, Delft, The Netherlands. ${ }^{3}$ Institute for Arts, Music and Media, Heidelberg University of Education, Heidelberg, Germany. 
Received: 3 March 2020 Accepted: 31 March 2020

Published online: 16 June 2020

\section{References}

Allen, I. E., \& Seaman, J. (2014). Grade change: Tracking online education in the United States. Babson Survey Research Group and The Sloan Consortium.

Beaudry, A. (2009). Coping with information technology. In Handbook of research on contemporary theoretical models in information systems, (pp. 516-528). IGl Global.

Beaudry, A., \& Pinsonneault, A. (2005). Understanding user responses to information technology: A coping model of user adaptation. MIS Quarterly, 29(3), 493-524.

Birch, D., \& Burnett, B. (2009). Bringing academics on board: Encouraging institution-wide diffusion of e-learning environments. Australasian Journal of Educational Technology, 25(1), 117-134.

Bolliger, D. U., \& Wasilik, O. (2009). Factors influencing faculty satisfaction with online teaching and learning in higher education. Distance Education, 30, 103-116.

Collis, B., \& van der Wende, M. (2002). Models of technology and change in higher educa- tion. Twente. The Netherlands: Center for Higher Education Policy Studies.

Creswell, J. W. (2014). Educational research: Planning, conducting and evaluating quantitative and qualitative research. Essex: Pearson Education Limited.

Evans, S., \& Myrick, J. G. (2015). How MOOC instructors view the pedagogy and purposes of massive open online courses. Distance Education, 36(3), 295-311.

Folkman, S. (1992). Making the case for coping. In B. N. Carpenter (Ed.), Personal coping: Theoo', research, and applications, (pp. 31-46). New York: Praeger.

Folkman, S., Lazarus, R. S., Gruen, R. J., \& De-Longis, A. (1986). Appraisal, coping, health status and psychological symptoms. Journal of Personality and Social Psychology, 50(3), 571-579.

Hannon, J. (2009). Breaking down online teaching: Innovation and resistance. Australasian Journal of Educational Technology, 25(1), 14-29.

Hsieh, H. F., \& Shannon, S. E. (2005). Three approaches to qualitative content analysis. Qualitative Health Research, 15(9), 1277-1288.

Jenkins, M., Browne, T., Walker, R., \& Hewitt, R. (2010). The development of technology enhanced learning: Findings from a 2008 survey of UK higher education institutions. Interactive Learning Environments, 18(1), 1-19.

Kebritchi, M., Lipschuetz, A., \& Santiague, L. (2017). Issues and challenges for teaching successful online courses in higher education: A literature review. Journal of Educational Technology Systems, 46(1), 4-29.

Lazarus, R. (1966). Psychological Stress and the Coping Process. New York: McGraw-Hill.

Lazarus, R. S., \& Folkman, S. (1984). Stress, appraisal, and coping. New York: Springer Pub- lishing Company.

Macfarlane, B. (2011). The morphing of academic practice: Unbundling and the rise of the Para-academic. Higher Education Quarterly, 65(1), 59-73.

Mayring, P. (2000). Qualitative content analysis. Forum: Qualitative Social Research, 1(2) Retrieved March 10, 2005, from http:// www.qualitative-research.net/fqs-texte/2-00/02-00mayring-e.htm.

McGrath, C., \& Bolander Laksov, K. (2014). Laying bare educational crosstalk: A study of discursive repertoires in the wake of educational reform. International Journal for Academic Development, 19(2), 139-149.

McGrath, C., Stenfors-Hayes, T., Roxå, T., \& Bolander Laksov, K. (2017). Exploring dimensions of change: The case of MOOC conceptions. International Journal for Academic Development, 22(3), 257-269.

Moos, R. H., \& Holahan, C. J. (2003). Dispositional and contextual perspectives on coping: Toward an integrative framework. Journal of Clinical Psychology, 59(12), 1387-1403.

Nambisan, S., Lyytinen, K., Majchrzak, A., \& Song, M. (2017). Digital Innovation Management: Reinventing innovation management research in a digital world. Mis Quarterly, 41(1).

Nascimbeni, F., \& Burgos, D. (2016). In search for the open educator: Proposal of a definition and a framework to increase openness adoption among university educators. The International Review of Research in Open and Distributed Learning, 17(6), 1-17.

Ozturk, H. T. (2015). Examining value change in MOOCs in the scope of connectivism and open educational resources movement. International Review of Research in Open and Distributed Learning, 16(5), 1-25.

Rogers, E. M. (2002). Diffusion of preventive innovations. Addictive Behaviors, 27, 989-993.

Russell, C. (2009). A systemic framework for managing e-learning adoption in campus universities: Individual strategies in context. ALT-J: Research in Learning Technology, 17(1), 3-19.

Schneckenberg, D. (2009). Understanding the real barriers to technology-enhanced in- novation in higher education. Educational Research, 51(4), 411-424.

Schophuizen, M., Kreijns, K., Stoyanov, S., \& Kalz, M. (2018). Eliciting the challenges and opportunities organizations face when delivering open online education: A group-concept mapping study. The Internet and Higher Education, 36, 1-12.

Surfnet (2017). Stimuleringsregeling open en online onderwijs. Retrieved from: http://www.scienceguide.nl/media/1878927/ flyer_stimuleringsregeling_open_en_online_onderwijs_ronde_3_web.pdf.

Yuan, L., \& Powell, S. (2013). MOOCs and open education: Implications for higher edu-cation. Retrieved fromhttp:// publications.cetisac.uk/2013/667. M. Schophuizen et al. The Internet and Higher Education, 36(2018), 1-1212.

Zellweger, F. (2007). Faculty adoption of educational technology. Educause Quarterly, 30(1), 66-69.

Zhu, C. (2015). Organisational culture and technology-enhanced innovation in higher education. Technology, Pedagogy and Education, 24(1), 65-79.

\section{Publisher's Note}

Springer Nature remains neutral with regard to jurisdictional claims in published maps and institutional affiliations. 